\title{
Effects of sodium nitrate on the growth and proximate composition of the indigenous marine microalgae Tetraselmis chuii (Butcher, 1959)
}

\author{
Sanzib Kumar Barman ${ }^{1,2}$ (D), Helena Khatoon ${ }^{3}$ (D), Mohammad Redwanur Rahman ${ }^{3}$ (D), Sabuj Kanti Mazumder ${ }^{4}$ (D), \\ Shanur Jahedul Hasan ${ }^{5}$ (i)
}

Cite this article as: Barman, S.K., Khatoon, H., Rahman, MR., Mazumder, SK., \& Hasan, S.J. Effects of sodium nitrate on the growth and proximate composition of the indigenous marine microalgae Tetraselmis chuii (Butcher, 1959). Aquatic Sciences and Engineering, 37(1), 46-52.

\section{ORCID IDs of the author: S.K.B. 0000-0002-9011-1067; H.K. 0000-0001-5896-0213; M.R.R. 0000-0002-2607-8223; S.J.H. 0000-0002-8000-0275 \\ 'Department of Agrifood Production and Environmental Science, Universita' degli Studi di Firenze (UNIFI), Florence, Italy \\ ${ }^{2}$ Department of Fishery Resources \\ Conservation and Management, Khulna Agricultural University, Khulna-9100, Bangladesh \\ ${ }^{3}$ Department of Aquaculture, Chattogram Veterinary and Animal Sciences University (CVASU)-4225, Bangladesh \\ ${ }^{4}$ Department of Genetics and Fish Breeding, Bangabandhu Sheikh Mujibur Rahman Agricultural University, Gazipur 1706, Bangladesh \\ ${ }^{5}$ Bangladesh Fisheries Research Institute, Mymensingh 2201, Bangladesh \\ Submitted: \\ 17.07.2021 \\ Revision Requested: \\ 17.11.2021 \\ Last Revision Received: \\ 23.11.2021 \\ Accepted: \\ 20.12.2021 \\ Online Published: \\ 31.12.2021 \\ Correspondence: \\ Helena Khatoon \\ E-mail: \\ helena@vasu.ac.bd}

\begin{abstract}
Nitrogen is one of the fundamental nutrients for algal growth, underpinning the microalgal biochemical composition. Therefore, this study compared the growth and proximate compositions of Tetraselmis chuii (Butcher, 1959), cultured in different nitrate $\left(\mathrm{NaNO}_{3}\right)$ concentrations $(25,50,100$, 200 and $500 \mathrm{mg} \mathrm{L}^{-1}$ ). Thus, the cell density, optical density, specific growth rate and division rate of T. chuii were measured daily. Furthermore, protein and carbohydrate contents were also determined in the stationary phase. The results showed that $T$. chuii cultivated in a $\mathrm{NaNO}_{3}$ concentration of $500 \mathrm{mg} \mathrm{L}^{-1}$ had significantly $(\mathrm{p}<0.05)$ higher growth in terms of cell density, biomass, optical density, specific growth rate and division rates compared with other concentrations. Likewise, protein content was also significantly higher under the $\mathrm{NaNO}_{3}$ concentration of $500 \mathrm{mg} \mathrm{L}^{-1}$, whereas significantly $(p<0.05)$ higher carbohydrate content was found at $25 \mathrm{mg} \mathrm{L}^{-1} \mathrm{NaNO}_{3}$ compared with the other concentrations, showing a contrary trend between protein and carbohydrate concentrations, respectively. Since the primary focus has been on improving the quality of microalgal biomass in order to develop novel processes and products, this is the first study to use higher concentrations of modified nitrate on T. chuii isolated from the coastal area of Bangladesh. Thus the indigenous marine $T$. chuii had significantly utilised $\mathrm{NaNO}_{3}$ concentrations with higher growth and proximate contents in this study. However, further study is needed on microalgal genetics and metabolic engineering to create a new molecular era of the indigenous marine microalgae isolated from the coastal water of Bengal.
\end{abstract}

Keywords: Nitrogen concentrations, marine microalgae, growth, proximate composition

\section{INTRODUCTION}

Microalgae are vital components in the food chain of aquatic ecosystems (Sathasivam et al., 2019). Their fast growth rates and high value of photosynthetic efficacies (Mostafa, 2012) mean that they potentially have better capacities for $\mathrm{CO}_{2}$ moderation than terrestrial plants do (Nigam \& Singh, 2011). Microalgae are widely used for larval feeding (Khatoon et al., 2013) because of their positive effects on the growth, survival and hatching of aquatic animals. They are also considered potential probiotics in aquaculture because of their antibacterial prop- erties and effective antioxidant system. With the acceleration of climate change, there is a great demand for the development of alternative energy sources with a reduced environmental impact. Microalgae as a source of biofuel and renewable feedstocks could be part of the solution (Ramanna, Rawat, \& Bux, 2017).

Nitrogen is fundamental for all functional and structural proteins, including chlorophylls in microalgae. The availability of nitrogen is crucial for microalgal growth (Cai, Park, \& Li, 2013). Studies have shown that nitrogen limitation in the culture medium increases lipid or carbohy- 
drate content, but it reduces protein synthesis of microalgal biomass, thus reducing microalgae's cell growth rate (Ho et al., 2014). Thus, the physicochemical structure of marine microalgae depends not only on the species but also on the growing conditions; for instance, temperature, salinity, $\mathrm{pH}$, lighting conditions (intensity and photoperiod), nutrients and medium agitation all play an important role (Khatoon et al., 2014; Bartley et al., 2016).

Tetraselmis is a genus of rapidly growing flagellated marine chlorophytes that can tolerate a wide variety of physical conditions (Khatoon et al., 2014). Tetraselmis chuii, the species of interest in this study, has recently been approved as a novel food in Europe and may play an important role in supplying essential nutrients because of its high protein, lipid, essential fatty acid and sterol contents (Ghezelbash et al., 2008). Thus, T. chuii can be economically important, and there is a need to optimise the growth rate for the production of this microalga. At the same time, the availability of nitrogen needs to be assured to accomplish optimum carbohydrate production and a rational growth rate (Razaghi, Godhe, \& Albers, 2014). Although growth, biochemical composition and different nutritional aspects of $T$. chuii have been studied (Khatoon et al., 2018), there is little information available on the effects of different nitrogen concentrations on the growth and proximate composition of indigenous marine Tetraselmis species isolated from the Bay of Bengal coast of Bangladesh. Some previous studies have considered the effects of different nitrogen concentrations on T. chuii, but the present study was the first to be conducted in a tropical environment, so its region is geographically isolated from the regions described in other studies. Most previous studies have been conducted using very low concentrations of nitrogen, but in this study, a higher concentration of nitrogen was used to evaluate the growth and proximate composition of this indigenous species for the first time. This will help to optimise the nitrogen concentration for higher growth of T. chuii. In this study, T. chuii was considered because it has high nutritive value, enabling its high potential as feed in aquaculture (Kim, Mujtaba, \& Lee, 2016). The main interest was to enhance the microalgal biomass quality so that innovative processes and products can be established. The biochemical composition of microalgae can be modified and improved by manipulating nutrient concentrations. Therefore, the objective of this study was to determine the effects of different nitrogen concentrations on the growth and proximate composition of indigenous T. chuii.

\section{MATERIALS AND METHODS}

\section{Sample collection, culture and maintenance}

The indigenous marine microalgae T. chuii strain (CVASUAO02) was obtained from the pure stock culture of the Department of Aquaculture, Faculty of Fisheries, Chattogram Veterinary and Animal Sciences University, Bangladesh. Filtered natural seawater was used as the seawater base, and the salinity was set at 26 ppt confirmed by a hand refractometer (Refractometer: Atago ATC- S/ Mill- E Salinity 0 - 100\%, Japan). The seawater was autoclaved at $121^{\circ} \mathrm{C}$ for $15 \mathrm{~min}-$ utes (DAC 60 Autoclave). A healthy and good stock of microalgae was maintained by observing its morphological features under the microscope. The health status of the cells was considered based on the three following criteria: the cells had to be oval in shape and green in colour, and they could not be found settled at the bottom of the flask. To maintain a healthy stock, T. chuii was cultured in an Erlenmeyer flask containing Conway medium at $24 \pm 1{ }^{\circ} \mathrm{C}$ and a light intensity of $150 \mu \mathrm{E} \mathrm{m} \mathrm{m}^{-2} \mathrm{~s}^{-1}$, maintained using cool fluorescent light. Sub-culturing was done every 2 weeks to prepare the required stock for the main experiment.

\section{Modified minerals stock solution preparation}

A stock solution modified in terms of its main mineral contents with different $\mathrm{N}$ concentrations was prepared, with sodium nitrate $\left(\mathrm{NaNO}_{3}\right)$ used as the main source of nitrogen. The procedure was adapted from James (1996). Hence, the stock solution was prepared with five different treatments, where $100 \mathrm{mg} \mathrm{L}^{-1}$ of $\mathrm{NaNO}_{3}$ was used as the control treatment (see Table 1). Each solution was tightly capped in a Schott Duran ${ }^{\circledR}$ bottle and stored in a refrigerator (Samsung SilverNano) until further use.

\section{Determination of growth curve}

Table 1. Different concentrations of nitrate $\left(\mathrm{NaNO}_{3}\right)$ with the corresponding $\mathrm{N}$ concentrations of each treatment for the study on growth of Tetraselmis chuii.

\begin{tabular}{lcc}
\hline Treatments & $\begin{array}{c}\mathbf{N a N O}_{3} \\
\text { concentration } \\
\text { (mg L-1) }\end{array}$ & $\begin{array}{c}\text { Corresponding N } \\
\text { concentration } \\
\text { (mg L-1) }\end{array}$ \\
\hline Treatment 1 $\left(\mathrm{T}_{1}\right)$ & 25 & 4.125 \\
Treatment 2 $\left(\mathrm{T}_{2}\right)$ & 50 & 8.25 \\
Control 3 $\left(\mathrm{T}_{3}\right)$ & 100 & 16.5 \\
Treatment 4 $\left(\mathrm{T}_{4}\right)$ & 200 & 33.0 \\
Treatment 5 $\left(\mathrm{T}_{5}\right)$ & 500 & 82.5
\end{tabular}

The growth curve experiment was conducted in sterile $500 \mathrm{~mL}$ borosilicate Erlenmeyer flasks, where the T. chuii culture volume was $300 \mathrm{~mL}$ ( $270 \mathrm{~mL}$ of Conway medium and $30 \mathrm{~mL}$ of stock of $T$. chuii). This was done in triplicate. The cultures were maintained at $24 \pm 1{ }^{\circ} \mathrm{C}$ at a light intensity of $150 \mu \mathrm{E} \mathrm{m} \mathrm{m}^{-2} \mathrm{~s}^{-1}$ using cool fluorescent light for $24 \mathrm{~h}$ of continuous lighting and aerated continuously with natural sterile air using an air pump. Growth curves based on cell density (cells $\mathrm{mL}^{-1}$ ) and optical density $(450 \mathrm{~nm})$ measurement were constructed. The highest cell density $\left(6.86 \times 10^{6}\right.$ cells $\mathrm{mL}^{-1}$ ) and optical density (0.327) was found at Day 8 , indicating the stationary phase of the growth curve and the beginning of the death phase (Fig. 1).

\section{Experimental design}

Fifteen autoclaved $500 \mathrm{~mL}$ borosilicate Erlenmeyer flasks were used and filled with approximately $100 \mathrm{~mL}$ of culture media, 30 $\mathrm{mL}$ of $T$. chuii stock culture and $170 \mathrm{~mL}$ of Conway medium. The cultures were maintained at $24 \pm 1{ }^{\circ} \mathrm{C}$ at a light intensity of $150 \mu \mathrm{E}$ $\mathrm{m}^{-2} \mathrm{~s}^{-1}$ using cool fluorescent light for $24 \mathrm{~h}$. The cultures were aerated with natural sterile air using an air pump. The flask openings were closed with autoclaved cotton, each with a sterile pipette aeration tube inserted through the cotton into the flask. The growth of the cultures was monitored daily throughout the experiment. Finally, T. chuii cultures were centrifuged (Hitachi ${ }^{\circledR}$ High- Speed Refrigerated Centrifuge, himac CR 21G-II) 2 days 


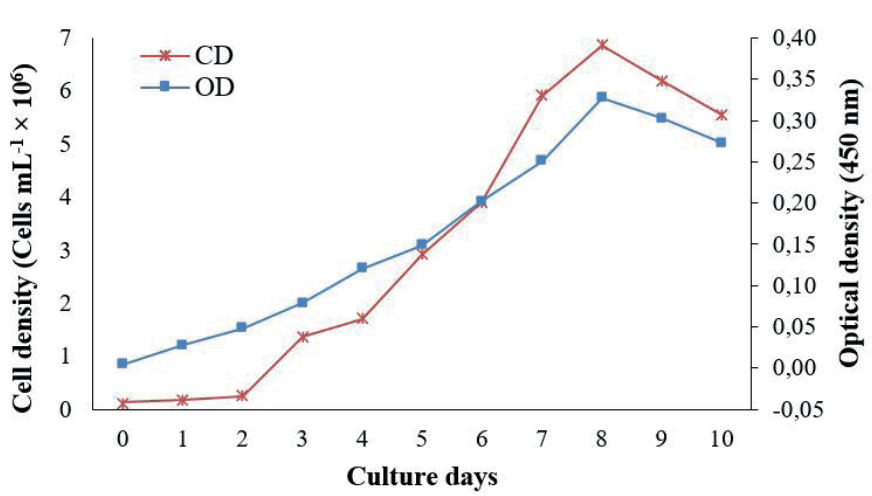

Figure 1. Growth curve of Tetraselmis chuii in terms of cell density (CD) and optical density (OD), cultured in Conway medium

before reaching the stationary phase (based on the growth curve experiment) to obtain pellets for the main experiment. The pellets were rinsed twice with sterilised distilled water before being transferred randomly into fresh medium. Microalgal pellets were randomly transferred into fifteen flasks with a $2 \mathrm{~L}$ capacity, containing $1.5 \mathrm{~L}$ of culture medium with different $\mathrm{NaNO}_{3}$ concentrations. The growth of the culture was monitored in terms of cell density, biomass, optical density and specific growth rate. The water salinity and $\mathrm{pH}$ were maintained at $26 \mathrm{ppt}$ and $7.3-7.5$, respectively; nevertheless, the $\mathrm{CO}_{2}$ concentration was adjusted through aeration during the experimental period. The experiment was conducted in a controlled condition in the laboratory.

\section{Collection of freeze-dried sample}

At the end of the experiment, the matured T. chuii cells were harvested in the stationary phase (depending on different $\mathrm{N}$ concentrations of five treatments) by centrifugation at $7000 \mathrm{rpm}$ for 3 minutes, followed by rinsing twice with sterilised distilled water. Since the highest productivity (cell density and biomass) and matured cells (due to higher nutrition level) were found at the end of the exponential phase, i.e. indicating the stationary phase of $T$. chuii growth (according to the growth curve), microalgae were harvested at this phase (Araujo et al., 2020). The cells were then dried (overnight at $60^{\circ} \mathrm{C}$ ) and the dried biomass was at $-20^{\circ} \mathrm{C}$ for proximate composition analysis.

\section{Determination of growth parameters}

Cell density, biomass and optical density were measured to determine microalgal growth. Cell density was determined using a haemocytometer (Hawksley AC1000, UK) according to the method reported by Lavens \& Sorgeloos (1996). For determination of biomass, $1 \mathrm{~mL}$ of culture aliquoted from each of the flasks was filtered onto the pre-weighed GF/C (Whatman glass microfiber filters combine) glass fibre filters using a vacuum pump filtration unit (Millipore). Then, the filters were dried at $100{ }^{\circ} \mathrm{C}$ for $4 \mathrm{~h}$ and subsequently cooled in the desiccator (Nalgene) for $15 \mathrm{~min}$. Next, the filter papers were individually weighed (AND, GR-200), and the biomass (dry weight basis) was determined for each sample. Optical density was determined using a spectrophotometer (UV-1601 UV Visible Spectrophotometer, Shimadzu). The absor- bance readings were taken at a wavelength of $450 \mathrm{~nm}$, considering the culture medium for T. chuii as the blanks (Lavens \& Sorgeloos, 1996).

Determination of specific growth rate (SGR) and division rate The specific growth rate (SGR, $\mu$ day $\left.^{-1}\right)$ of $T$. chuii of different treatment was calculated using the following equation, developed by Clesceri, Greenberg, \& Trussel (1989):

$S G R=\ln \left(X_{2}-X_{1}\right) / t_{2}-t_{1}$

where $X_{1}$ represents the biomass concentration at the beginning of the selected time interval, $X_{2}$ represents the biomass (dry weight basis) concentration at the end of the selected time interval and $t_{2}-t_{1}$ is the selected time (in days) for the determination of biomass (dry weight) of T. chuii.

The division rate (day ${ }^{-1}$ ) of the indigenous $T$. chuii was calculated using the following equation (Teo et al., 2014):

Division rate $=\mathrm{SGR} / \ln 2$

\section{Determination of proximate compositions Protein determination}

For every sample, $5 \mathrm{mg}$ of freeze-dried microalgae was taken to make a $25 \mathrm{~mL}$ solution by mixing homogenously with distilled water. From this $25 \mathrm{~mL}$ microalgal solution, $0.5 \mathrm{~mL}$ was taken for protein analysis. Prior to the start of the analysis, Reactive 1 (1\% NP tartrate) and Reactive 2 ( $2 \mathrm{~g}$ of $\mathrm{NaCO}_{3}$ in $100 \mathrm{~mL}$ of $0.1 \mathrm{NaOH}$ ) were prepared. For protein analysis, $50 \mathrm{~mL}$ of Reactive 2 and 1 $\mathrm{mL}$ of Reactive 1 were mixed. Then, $0.5 \mathrm{~mL}$ of microalgal solution was added with $0.5 \mathrm{~mL}$ of $1 \mathrm{~N} \mathrm{NaOH}$ and kept in a $100{ }^{\circ} \mathrm{C}$ water bath for 5 minutes. Afterwards, it was cooled in a water bath, and $2.5 \mathrm{~mL}$ of the prepared mixed reagent was added 10 minutes after cooling. The mixed solution was added with $0.5 \mathrm{~mL}$ of Folin Ciocalteau reagent and then kept in the dark for 30 minutes. Standard protein concentrations were prepared using bovine serum albumin. The absorbance was measured using a spectrophotometer (Shimadzu UV-1601, Japan) at a wavelength of 750 nm (Lowry et al., 1951).

\section{Carbohydrate determination}

Freeze-dried microalgae ( $5 \mathrm{mg}$ ) were used to make a $25 \mathrm{~mL}$ solution by mixing homogenously with distilled water. Prior to the start of the analysis, $5 \%$ phenol solution and concentrated sulfuric acid were prepared. For carbohydrate analysis, $1 \mathrm{~mL}$ of microalgal solution was taken and a $5 \%$ phenol solution was added, followed by $5 \mathrm{~mL}$ of sulfuric acid. The standard was prepared using glucose. The optical density was measured at $488 \mathrm{~nm}$ in a spectrophotometer (Shimadzu UV-1601, Japan; Dubois et al., 1956).

\section{Statistical analysis}

The results of the growth and proximate compositions were analysed by one-way analysis of variance (ANOVA) considering the nitrate $\left(\mathrm{NaNO}_{3}\right)$ concentrations with a significance level of 95\% $(p<0.05)$ as well as Tukey multiple comparisons test (where applicable). The graphical presentation of the growth parameters and proximate compositions (\% dry weight) with different treatments were analysed by SPSS software and Microsoft Excel. All results were presented as mean \pm standard deviation. 


\section{RESULTS AND DISCUSSION}

\section{Microalgal growth under different nitrate $\left(\mathrm{NaNO}_{3}\right)$ concentrations}

The cell density, biomass and optical density of the indigenous marine microalga T. chuii cultured in controlled conditions under five different concentrations of $\mathrm{NaNO}_{3}$ are shown in Fig. 2. The results showed that $T$. chuii cultured at different $\mathrm{NaNO}_{3}$ concentrations stretched their stationary phase at different days, although no significant difference was found between the $\mathrm{T}_{4}(200$ $\left.\mathrm{mg} \mathrm{L}^{-1}\right)$ and $T_{5}\left(500 \mathrm{mg} \mathrm{L}^{-1}\right)$ treatments. The comparison between $T_{4}$ and $T_{5}$ was based on the culture days in the stationary phase, in which both treatments indicated the same stationary phase at day 9. In sum, there were no significant differences for biomass. While this finding doesn't support most other studies in which the increasing $\mathrm{NaNO}_{3}$ concentrations indicate the increment of biomass production, the biomass productivity of microalgae is highly dependent on the culture media as well as the species and strain of microalgae (Araujo et al., 2020), which might be consistent with the present findings as this new strain is isolated from the Bay of Bengal. Furthermore, the corresponding $\mathrm{N}$ concentrations in the growth medium for each treatment were significantly different with respect to the nitrate $\left(\mathrm{NaNO}_{3}\right)$ concentrations (Table 1).

Nutrient convenience has a significant impact on the growth and biochemical composition of marine microalgae (Xia et al., 2013). Moreover, the plentiful supply of nutrients (nitrogen, phosphorus, potassium nitrate, etc.) is the principle of attaining high growth rates in microalgal cells (Xia et al., 2013). The growth rate declines and ceases only when the metabolic requirements do not match the supplied nutrients. There are also other important factors (temperature, light, salinity, $\mathrm{pH}$, etc.) that might distress the growth and biochemical compositions of microalgae (Yeh \& Chang, 2012). Microalgae growth and biomass are influenced by light and photoperiod during culture (Ahmad et al., 2020; Yusof et al., 2021). Furthermore, the length of light and dark (24:0h) exposure until the saturation point, at which the maximum photosynthetic rate is reached, may influence cellular contents such aschlorophyll and antioxidants (Darvehei, Bahri, \& Moheimani, 2018; Yusof et al., 2021). However, in this study, sodium nitrate, a source of nitrogen, was considered one of the most crucial nutrients for microalgal cell growth because its concentrations in the growth medium significantly affected the growth rate of algal cells (Wu \& Miao, 2014), as well as the biochemical compositions of microalgae (Kim, Mujtaba, \& Lee, 2016).

Zarrinmehr et al. (2020) studied the effects of different nitrogen concentrations $\left(0,36,72,144\right.$ and $\left.288 \mathrm{mg} \mathrm{L}^{-1}\right)$ on the growth and biochemical composition of Isochrysis galbana. Their study revealed that diminishing concentrations of nitrogen reduce the cell growth and biomass production of I. galbana. In the present study, the lowest concentration of $\mathrm{NaNO}_{3}\left(25 \mathrm{mg} \mathrm{L}^{-1}\right)$ showed comparatively very low cell growth; however, the highest cell density $\left(3.00 \times 10^{6}\right.$ cells $\left.\mathrm{mL}^{-1}\right)$ was recorded with the maximum concentration of $\mathrm{NaNO}_{3}\left(500 \mathrm{mg} \mathrm{L}^{-1}\right)$. These results are consistent with Huang et al. (2013), who also reported that the increment of nitrogen supply significantly increased the growth rates of three microalgae species, namely, Tetraselmis subcordiformis
(Wille) Butcher, 1959; Nannochloropsis oculata (Droop) Hibberd, 1981; and Pavlova viridis Tseng, Jiaofu, \& Zhefu, 1992. These results were also consistent with the optical density measurements of the present study. Studies also reported that some speciesScenedesmus acutus, Chlorella vulgaris, Nannochloropsis sp. and Nannochloropsis oleoabundans- grow well in nitrogen-deficient environments by exploiting their intracellular nitrogen reserves, such as pigment-protein molecules (Gu et al., 2015); this result also supports the present findings (i.e. growing cell concentration under low concentrations of nitrogen). However, the studies of Araujo et al. (2020) have found the highest productivity at low $\mathrm{NaNO}_{3}$ concentrations for the sole microalgae T. chuii, which doesn't support the present study findings. This is because of very low concentrations ( 25 to $75 \mathrm{mg} \mathrm{L}^{-1}$ ) of $\mathrm{NaNO}_{3}$ have been conducted in their study, but in this study, a higher concentration of nitrogen was used to evaluate the growth and proximate composition of this indigenous species for the first time. Thus, the aim of this study will help to optimise the nitrogen concentration for higher growth of $T$. chuii.

The marine microalgae T. chuii efficiently utilised nitrate $\left(\mathrm{NaNO}_{3}\right)$ for growth and the present results showed that the increased $\mathrm{N}$ concentrations in the culture media significantly enhanced the growth performance. However, the maximum density was found in $T_{5}\left(500 \mathrm{mg} \mathrm{L}^{-1}\right)$ treatment (Fig. 2a) with a respective cell density of $3.00 \times 10^{6}$ cells $\mathrm{mL}^{-1}$; lower cell density was observed in $T_{1}$ (25 $\mathrm{mg} \mathrm{L}^{-1}$ ) at $1.05 \times 10^{6}$ cells $\mathrm{mL}^{-1}$. There were significant differences among all the treatments of $\mathrm{NaNO}_{3}$ concentrations when compared with the control treatment $\mathrm{T}_{3}\left(100 \mathrm{mg} \mathrm{L}^{-1} ;\right.$ Fig. 2a). The increase of nitrate $\left(\mathrm{NaNO}_{3}\right)$ concentrations in the culture media, ranging from 4.125 to $82.5 \mathrm{mg} \mathrm{L}^{-1}$ of $\mathrm{N}$ ( $\mathrm{N}$ concentrations ranges indicated the same as nitrate concentrations based on different $\mathrm{NaNO}_{3}$ concentrations in the medium), significantly induced the increment of biomass production. The biomass concentration of T. chuii in the stationary phase under $4.1 \mathrm{mg} \mathrm{L}^{-1} \mathrm{~N}\left(\mathrm{~T}_{1}\right)$ was only $0.0094 \mathrm{~g} \mathrm{~L}^{-1}$ (23\% increase of biomass), whereas the maximum biomass concentration (in dry weight) was $0.0140 \mathrm{~g} \mathrm{~L}^{-1}$ in the stationary phase (81\% increase of biomass) under $82.5 \mathrm{mg} \mathrm{L}^{-1} \mathrm{~N}\left(\mathrm{~T}_{5}\right)$, representing a significant difference between the two results (Fig. 2b). Moreover, there was a significant difference in biomass production among all the treatments compared with the control treatment $\mathrm{T}_{3}\left(0.0123 \mathrm{~g} \mathrm{~L}^{-1}\right.$ of dry biomass), which exhibited about a $58 \%$ increase (comprising $16.5 \mathrm{mg} \mathrm{L}^{-1} \mathrm{~N}$ ) of dried biomass. $A$ similar trend was noted for optical density (OD), for which higher absorbance was recorded with increasing $\mathrm{N}$ concentrations for nitrate $\left(\mathrm{NaNO}_{3}\right.$; Fig. 2c).

Marine microalgae can utilise inorganic nitrogen for their growth and metabolic activities and increase their biomass concentrations in conjunction with the nitrogen-enriched condition (Rizwan et al., 2017). The present study findings also revealed that the increment of nitrogen $\left(\mathrm{NaNO}_{3}\right)$ supply in the medium significantly increased biomass production of $T$. chuii, but the contrary result was found for decreased concentrations of nitrogen. This finding was subsequently supported by Zarrinmehr et al. (2020), who also reported that the diminishing concentrations of nitrogen decreased the biomass production of I. galbana, whereas opposite results were found for increased nitrogen concentra- 

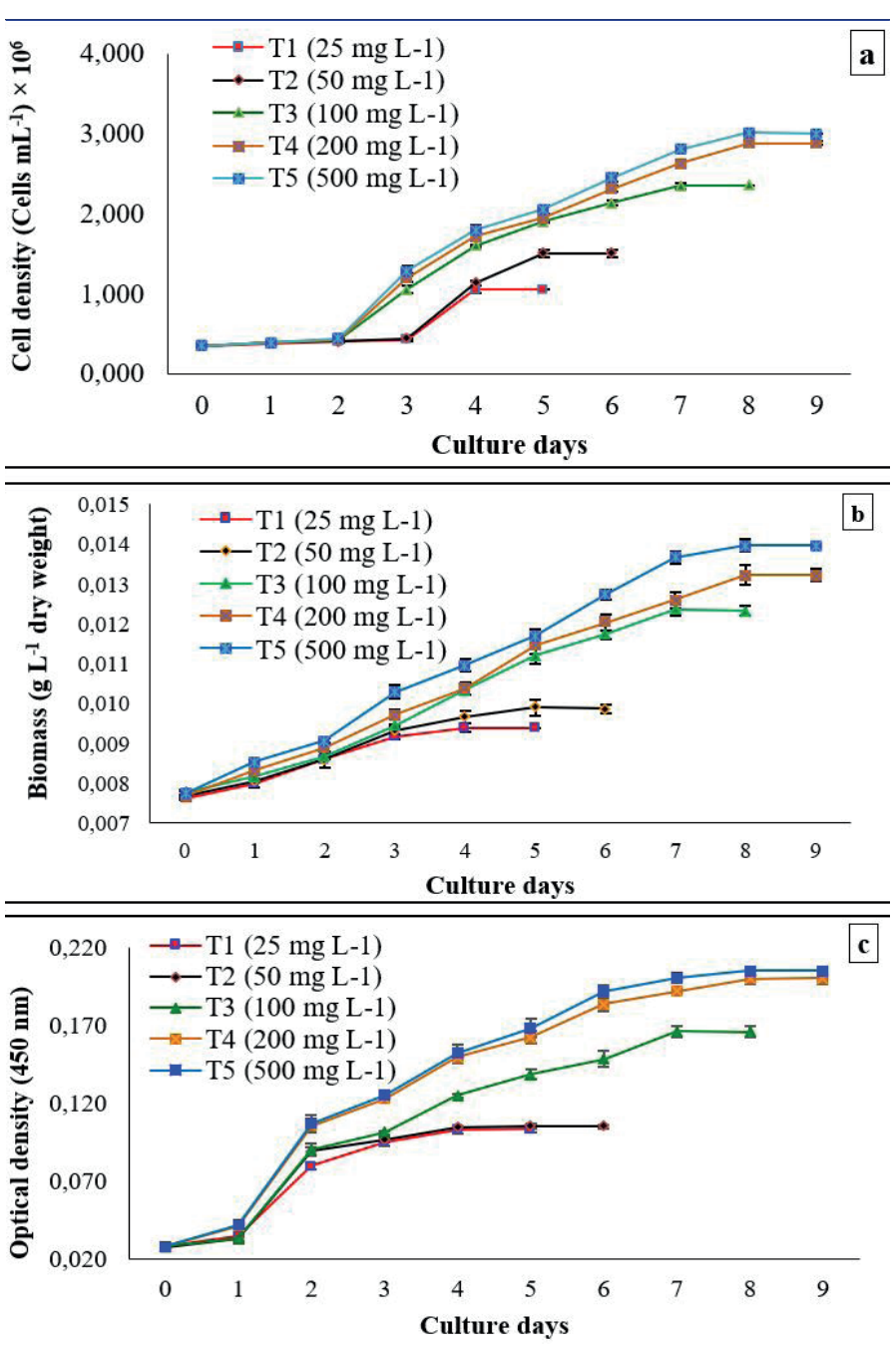

Figure 2. Effects of different $\mathrm{NaNO}_{3}$ concentrations on the growth of Tetraselmis chuii in terms of (a) cell density (cells $\mathrm{mL}^{-1}$ ), (b) biomass ( $\mathrm{g} \mathrm{L}^{-1}$ ) and (c) optical density (450 $\mathrm{nm}$; values are mean \pm standard deviation).

tions in the medium. Those findings were also consistent with the results reported by El-Kassas (2013), who stated that the cell density and biomass production of Picochlorum sp. decreased under the deficient condition of the major macro-nutrients, such as nitrogen or phosphorus, compared with the control treatments. Another important factor is mixing of water, which can also significantly affect the biomass production of microalgal cells. It is important to obtain the proper light absorptions in the culture medium to achieve appropriate growth and biomass production.

It is noteworthy that the culture volume of the present study was $1.5 \mathrm{~L}$ in each $2 \mathrm{~L}$ of the conical flask supplied with aeration of pure air (comprising $0.03 \% \mathrm{CO}_{2}$ ), resulting in a low volume of surface area. Thus, the small surface area was supposed to bring about the poor mixing rate and low light penetration in the medium, resulting in low biomass production. Mohsenpour \& Willoughby (2016) also reported that increased concentrations of $\mathrm{CO}_{2}$ in the air stream enhanced the $\mathrm{CO}_{2}$ fixation rate in Chlorella vulgaris, and the biomass concentrations increased with $5 \% \mathrm{CO}_{2}$ aeration compared with the pure air (comprising $0.03 \% \mathrm{CO}_{2}$ ) concentration, which varied in the present study findings because of the small volume of surface area and low percentage of $\mathrm{CO}_{2}$ concentrations through aeration. The research by Uggetti et al. (2018) also proved that the addition of $\mathrm{CO}_{2}$ through aeration induced the rise of biomass concentrations by between $66 \%$ and $100 \%$, in which proper mixing was achieved.

The present study findings showed a comparable trend for the SGR $\left(\mu\right.$ day $\left.^{-1}\right)$ and division rate of $T$. chuii, which increased with the increasing nitrogen concentrations (Table 2). The highest SGR $\left(0.0664 \mu\right.$ day $\left.^{-1}\right)$ and division rate $\left(0.0958\right.$ day $\left.^{-1}\right)$ were measured for treatment $\mathrm{T}_{5}\left(500 \mathrm{mg} \mathrm{L}^{-1}\right)$ with a $\mathrm{NaNO}_{3}$ concentration of $82.5 \mathrm{mg} \mathrm{L}^{-1} \mathrm{~N}$.

Table 2. Specific growth rate (SGR) and division rate of Tetraselmis chuii under different concentrations of $\mathrm{NaNO}_{3}$. Values are Mean \pm SD (standard deviation).

\begin{tabular}{lcc}
\hline Treatment & SGR $\boldsymbol{\mu}$ day $^{-1}$ & Division rate day \\
\hline$T_{1}$ & $0.0425 \pm 0.0002$ & $0.0613 \pm 0.0001$ \\
$T_{2}$ & $0.0419 \pm 0.0001$ & $0.0604 \pm 0.0003$ \\
$T_{3}$ & $0.0569 \pm 0.0003$ & $0.0821 \pm 0.0002$ \\
$T_{4}$ & $0.0599 \pm 0.0002$ & $0.0864 \pm 0.0001$ \\
$T_{5}$ & $0.0664 \pm 0.0001$ & $0.0958 \pm 0.0001$
\end{tabular}

Zhu et al. (2014) demonstrated that the specific growth rate of Chlorella zofingiensis was $0.48 \mu$ day $^{-1}$ under low concentrations of nitrogen in the medium, and this condition increased the SGR to $1.02 \mu$ day $^{-1}$ during nitrogen repletion. The present study findings were also consistent with Zarrinmehr et al. (2020), who reported that I. galbana can grow well in a nitrogen-enriched medium rather than a nitrogen-deficient condition.

\section{Effects of different nitrate (NaNO3) concentrations on pro- tein and carbohydrate content}

The different nitrate $\left(\mathrm{NaNO}_{3}\right)$ concentrations in the growth medium of $T$. chuii showed significant effects on protein and carbohydrate content (Fig. 3) in some treatments. The protein and carbohydrate contents exhibited significant changes of contrary trends in relation to their sufficient and deficient $\mathrm{N}$ concentrations for $\mathrm{NaNO}_{3}$, respectively (Fig. 3). The increased $\mathrm{N}$ concentrations in the culture medium significantly induced the increment of protein content ( $\%$ dry weight). The highest protein content of $37.57 \%$ dry weight (comprising $82.5 \mathrm{mg} \mathrm{L}^{-1} \mathrm{~N}$ ) was recorded from $\mathrm{T}_{5}\left(500 \mathrm{mg} \mathrm{L}^{-1}\right)$, and this result was significantly different from that of the control treatment $T_{3}$. In contrast, the carbohydrate content (\% dry weight) revealed the highest concentration, comprising $29.76 \%$ dry weight (corresponding concentration of $4.1 \mathrm{mg} \mathrm{L}^{-1} \mathrm{~N}$ ) in $\mathrm{T}_{1}\left(25 \mathrm{mg} \mathrm{L}^{-1}\right)$ for nitrate $\left(\mathrm{NaNO}_{3}\right)$, which was also significantly different with $T_{4}$ and $T_{5}$, and the control treatment $T_{3}$ (Fig. 3).

The availability of major nutrients has a significant effect on the proximate composition of microalgal cells (Xia et al., 2013). Microalgae generate both lipid and proteins when the carbon:nitrogen ratio is balanced, i.e. when there is a lot of nitrogen, that increases the net nitrogen consumption. But, when nitrogen is 


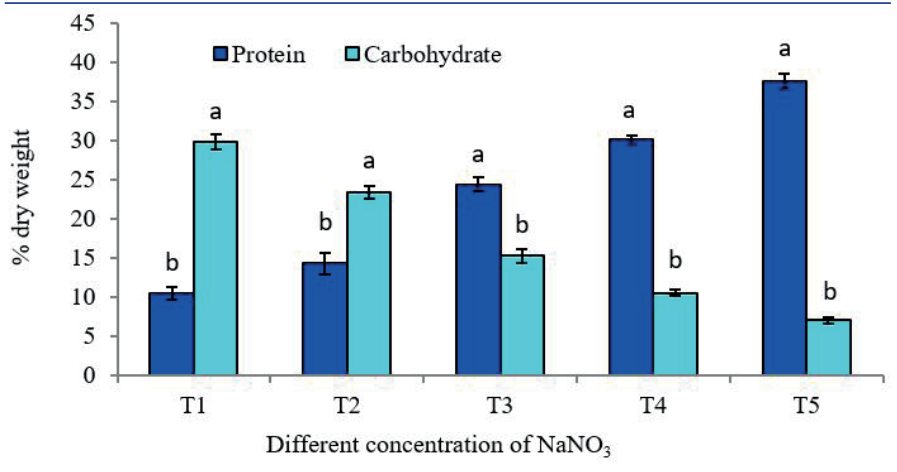

Figure 3. Proximate composition (\% dry weight) of $T$. chuii under differentsodium nitrate $\left(\mathrm{NaNO}_{3}\right)$ concentrations (values are mean \pm standard deviation). Letters indicate the significant levels of protein and carbohydrate among the different treatments.

scarce, microalgae produce fewer nitrogen-containing molecules and store lipids, resulting in a reduction in nitrogen consumption (Araujo et al., 2020). However, the suitable $\mathrm{N}$ concentrations for microalgal growth and proximate composition differ from species to species (Kim, Mujtaba, \& Lee, 2016). The present study findings revealed that the increased nitrogen concentrations in the growth medium significantly induced the protein content up to $37.57 \%$ (dry weight), while the opposite trend was found for carbohydrate concentrations. This finding was consistent with Kim, Mujtaba, \& Lee (2016), who also reported this trend for marine chlorophyte Tetraselmis sp., in which carbohydrate production increased up to $55 \%$ and protein concentrations gradually decreased under nitrogen-deficient conditions. The findings of this study proved that microalgae (T. chuii) cause protein accumulation in $\mathrm{N}$-sufficient culture conditions, while carbohydrate accumulation occurs in N-deficient conditions, which was also described by Kim, Mujtaba, \& Lee (2016). Guihéneuf \& Stengel (2015) also stated that the cellular carbohydrate concentrations of Porphyridium purpireum increased up to $40 \%$ during the $\mathrm{N}$-deficient logarithmic phase. A similar study conducted by Pancha et al. (2014) demonstrated that different nitrate concentrations, ranging from 247 to $0 \mathrm{mg} \mathrm{L}^{-1}$, decreased the protein percentage of Scenedesmus sp. from $47.75 \%$ to $16.87 \%$. Since nitrogen is the most important pioneer for protein synthesis, nitrogen deficiency is a common physiological response in microalgae to decreasing protein content (Zarrinmehr et al., 2020; Araujo et al., 2020). Although nitrogen deficiency is effective, easy and cost effective for biofuel production, it has some effects on cell physiology, such as decreases in proteins and chlorophyll, and it influences photosynthesis ability, resulting in the decreased growth rates (Ördög et al., 2012).

\section{CONCLUSION}

The indigenous (isolated from the Bay of Bengal) marine microalgae T. chuii was found to utilise sodium nitrate efficiently. Though most previous studies have been conducted using very low concentrations of nitrogen, the current study was conducted with higher concentrations of nitrogen to evaluate the growth and proximate composition of this indigenous species for the first time. It is noteworthy that the present study findings will help to enhance the nitrogen concentration for higher growth of indigenous T. chuii as well as to enhance both the protein and lipid content, directing possible future research efforts. In addition, future studies can include experiments on ways to improve the quality and quantity of protein and lipids in microalgae, especially those with commercial advantages. Furthermore, extensive research in the field of microalga genetics and metabolic engineering are necessary to determine methods of producing biofuel in continuous, economic and sustainable ways.

Conflict of interest: The author has declared no conflict of interest.

Ethics committee approval: The research has complied with all regional, national, and institutional ethical clearance and been approved.

Funding: This study was supported by a research grant funded by the Bangladesh Fisheries Research Institute (BFRI) and was a project of the University Grants Commission (UGC), Bangladesh, under the Chattogram Veterinary and Animal Sciences University (CVASU) campus.

Acknowledgments: The author was supported by an Erasmus Mundus Joint Master Degree in Tropical Biodiversity and Ecosystems Scholarship. The author would like to thank all the members of the Aquaculture Laboratory for their assistance during the study.

\section{REFERENCES}

Ahmad, M. T., Shariff, M., Md. Yusoff, F., Goh, Y. M. \& Banerjee, S. (2020). Applications of microalga Chlorella vulgaris in aquaculture. Reviews in Aquaculture, 12(1), 328-346. [CrossRef]

Araujo, G. S., Silva, J. W., Viana, C. A. \& Fernandes, F. A. (2020). Effect of sodium nitrate concentration on biomass and oil production of four microalgae species. International Journal of Sustainable Energy, 39(1), 41-50. [CrossRef]

Bartley, M. L., Boeing, W. J., Daniel, D., Dungan, B. N. \& Schaub, T. (2016). Optimization of environmental parameters for Nannochloropsis salina growth and lipid content using the response surface method and invading organisms. Journal of applied phycology, 28, 15-24. [CrossRef]

Butcher, R. W. (1959). An introductory account of the smaller algae of British coastal waters Part I. Introduction and Chlorophyceae. Fish Investig, 4, 1-74.

Cai, T., Park, S. Y. \& Li, Y. (2013). Nutrient recovery from wastewater streams by microalgae: status and prospects. Renewable and Sustainable Energy Reviews, 19, 360-369. [CrossRef]

Clesceri, L. S., Greenberg, A. E. \& Trussel, R. R. (1989). Standard methods for the examination of water and wastewater, Published by the Am. Publ. Health Assoc., Am. Water Works Assoc. and Water Pollution Control Fed.

Darvehei, P., Bahri, P. A. \& Moheimani, N. R. (2018). Model development for the growth of microalgae: A review. Renewable and Sustainable Energy Reviews, 97, 233-258. [CrossRef]

Dubois, M., Gilles, K. A., Hamilton, J. K., Rebers, P. T. \& Smith, F. (1956). Colorimetric method for determination of sugars and related substances. Analytical chemistry, 28(3), 350-356. [CrossRef]

El-Kassas, H. Y. (2013). Growth and fatty acid profile of the marine microalga Picochlorum sp. grown under nutrient stress conditions. The Egyptian Journal of Aquatic Research, 39(4), 233-239. [CrossRef] 
Ghezelbash, F., Farboodnia, T., Heidari, R. \& Agh, N. (2008). Biochemical effects of different salinities and luminance on green microalgae Tetraselmis chuii. Research Journal of Biological Sciences, 3(2), 217221.

Gu, H., Nagle, N., Pienkos, P. T. \& Posewitz, M. C. (2015). Nitrogen recycling from fuel-extracted algal biomass: residuals as the sole nitrogen source for culturing Scenedesmus acutus. Bioresource technology, 184, 153-160. [CrossRef]

Guihéneuf, F. \& Stengel, D. B. (2015). Towards the biorefinery concept: Interaction of light, temperature and nitrogen for optimizing the coproduction of high-value compounds in Porphyridium purpureum. Algal research, 10, 152-163. [CrossRef]

Hibberd, D. J. (1981). Notes on the taxonomy and nomenclature of the algal classes Eustigmatophyceae and Tribophyceae (synonym Xanthophyceae). Botanical journal of the linnean society. [CrossRef]

Ho, S. H., Ye, X., Hasunuma, T., Chang, J. S. \& Kondo, A. (2014). Perspectives on engineering strategies for improving biofuel production from microalgae-a critical review. Biotechnology advances, 32(8), 1448-1459. [CrossRef]

Huang, X., Huang, Z., Wen, W. \& Yan, J. (2013). Effects of nitrogen supplementation of the culture medium on the growth, total lipid content and fatty acid profiles of three microalgae (Tetraselmis subcordiformis, Nannochloropsis oculata and Pavlova viridis). Journal of Applied Phycology. [CrossRef]

James, D. B. (1996). Inception report on sea cucumber culture in Laamu Atoll, Maldives. Food and Agriculture Organization of the United Nations, Bangkok, TCP/MDV/4452 Field Document 1.

Khatoon, H., Banerjee, S., Yusoff, F. M. \& Shariff, M. (2013). Use of microalgal - enriched D iaphanosoma celebensis $S$ tingelin, 1900 for rearing L itopenaeus vannamei (B oone, 1931) postlarvae. Aquaculture Nutrition, 19, 163-171. [CrossRef]

Khatoon, H., Haris, H., Rahman, N. A., Zakaria, M. N., Begum, H. \& Mian, S. (2018). Growth, proximate composition and pigment production of Tetraselmis chuii cultured with aquaculture wastewater. Journal of Ocean University of China, 17 (3), 641-646. [CrossRef]

Khatoon, H., Rahman, N. A., Banerjee, S., Harun, N., Suleiman, S. S., Zakaria, N. H. \& Endut, A. (2014). Effects of different salinities and pH on the growth and proximate composition of Nannochloropsis sp. and Tetraselmis sp. isolated from South China Sea cultured under control and natural condition. International Biodeterioration \& Biodegradation, 95, 11-18. [CrossRef]

Kim, G., Mujtaba, G. \& Lee, K. (2016). Effects of nitrogen sources on cell growth and biochemical composition of marine chlorophyte Tetraselmis sp. for lipid production. Algae, 31(3), 257-266. [CrossRef]

Lavens, P. \& Sorgeloos, P. (1996). Manual on the production and use of live food for aquaculture (No. 361). Food and Agriculture Organization (FAO).

Lowry, O. H., Rosebrough, N. J., Farr, A. L. \& Randall, R. J. (1951). Protein measurement with the Folin phenol reagent. Journal of biological chemistry, 193, 265-275. [CrossRef]

Mohsenpour, S. F. \& Willoughby, N. (2016). Effect of $\mathrm{CO}_{2}$ aeration on cultivation of microalgae in luminescent photobioreactors. Biomass and Bioenergy, 85, 168-177. [CrossRef]

Mostafa, S. S. (2012). Microalgal biotechnology: prospects and applications. Plant science, 12, 276-314.

Nigam, P. S. \& Singh, A. (2011). Production of liquid biofuels from renewable resources. Progress in energy and combustion science, 37(1), 52-68. [CrossRef]
Ördög, V., Stirk, W. A., Bálint, P., van Staden, J. \& Lovász, C. (2012). Changes in lipid, protein and pigment concentrations in nitrogenstressed Chlorella minutissima cultures. Journal of Applied Phycology, 24(4), 907-914. [CrossRef]

Pancha, I., Chokshi, K., George, B., Ghosh, T., Paliwal, C., Maurya, R. \& Mishra, S. (2014). Nitrogen stress triggered biochemical and morphological changes in the microalgae Scenedesmus sp. CCNM 1077. Bioresource technology, 156, 146-154. [CrossRef]

Ramanna, L., Rawat, I. \& Bux, F. (2017). Light enhancement strategies improve microalgal biomass productivity. Renewable and Sustainable Energy Reviews, 80, 765-773. [CrossRef]

Razaghi, A., Godhe, A. \& Albers, E. (2014). Effects of nitrogen on growth and carbohydrate formation in Porphyridium cruentum. Open Life Sciences, 9(2), 156-162. [CrossRef]

Rizwan, M., Mujtaba, G., Rashid, N. \& Lee, K. (2017). Enhancing lipid production of Dunaliella tertiolecta by manipulating the interactive effect of salinity and nitrogen. Chemical and Biochemical Engineering Quarterly, 31(3), 199-207. [CrossRef]

Sathasivam, R., Radhakrishnan, R., Hashem, A. \& Abd_Allah, E. F. (2019). Microalgae metabolites: A rich source for food and medicine. Saudi journal of biological sciences, 26(4), 709-722. [CrossRef]

Teo, C. L., Atta, M., Bukhari, A., Taisir, M., Yusuf, A. M. \& Idris, A. (2014). Enhancing growth and lipid production of marine microalgae for biodiesel production via the use of different LED wavelengths. Bioresource technology, 162, 38-44. [CrossRef]

Tseng, C. K., Jiaofen, C. \& Zhefu, Z. (1992). On a new species of Pavlova (Prymnesiophyceae) from China. Chinese Journal of Oceanology and Limnology, 10(1), 23-30. [CrossRef]

Uggetti, E., Sialve, B., Hamelin, J., Bonnafous, A. \& Steyer, J. P. (2018). $\mathrm{CO}_{2}$ addition to increase biomass production and control microalgae species in high rate algal ponds treating wastewater. Journal of $\mathrm{CO}_{2}$ Utilization, 28, 292-298. [CrossRef]

Wu, H. \& Miao, X. (2014). Biodiesel quality and biochemical changes of microalgae Chlorella pyrenoidosa and Scenedesmus obliquus in response to nitrate levels. Bioresource Technology, 170, 421-427. [CrossRef]

Xia, S., Wan, L., Li, A., Sang, M. \& Zhang, C. (2013). Effects of nutrients and light intensity on the growth and biochemical composition of a marine microalga Odontella aurita. Chinese Journal of Oceanology and Limnology, 31(6), 1163-1173. [CrossRef]

Yeh, K. L. \& Chang, J. S. (2012). Effects of cultivation conditions and media composition on cell growth and lipid productivity of indigenous microalga Chlorella vulgaris ESP-31. Bioresource technology, 105, 120-127. [CrossRef]

Yusof, N. S., Yeong, Y. S., Zakeri, H. A., Wahid, M. E. A., Ab, N. \& Ghafar, N. Y. (2021). Photoperiod influenced the growth and antioxidative responses of Chlorella vulgaris, Isochrysis galbana, and Tetraselmis chuii. J Appl Pharm Sci, 11(4), 125-134.

Zarrinmehr, M. J., Farhadian, O., Heyrati, F. P., Keramat, J., Koutra, E., Kornaros, M. \& Daneshvar, E. (2020). Effect of nitrogen concentration on the growth rate and biochemical composition of the microalga, Isochrysis galbana. The Egyptian Journal of Aquatic Research, [CrossRef]

Zhu, S., Huang, W., Xu, J., Wang, Z., Xu, J. \& Yuan, Z. (2014). Metabolic changes of starch and lipid triggered by nitrogen starvation in the microalga Chlorella zofingiensis. Bioresource Technology, 152, 292298. [CrossRef] 